\title{
An Analysis of The Hospital Bylaws Policies to Protect Healthcare Workers Against Indictments of Adverse Events
}

\author{
*Ade Leana, **Adang Bachtiar \\ * Rumah Sakit Ketergantungan Obat Jakarta, Jalan Lapangan Tembak No. 75, Cibubur, Ciracas, Kota Jakarta Timur, Daerah \\ Khusus Ibukota Jakarta \\ ** Department Health Administration and Policy, Faculty of Public Health Universitas Indonesia
}

Email: adeleanacitra@yahoo.com

\begin{abstract}
One of the functions of hospital bylaws are a means to provide legal protection for all all parties that are related to the hospital. Legal protection is essential for prosecuted hospital staff members. One of the reasons for indictments is adverse events. The goal of this research is to discover how the hospital by-laws protects the hospital staff in the event of an indictment based on an adverse event and how the by-laws adhere to the guidelines in a comprehensive way. The research design used the qualitative method. The results of this research indicates that the hospital by-laws of RSKO Jakarta, although it has served as a protective method, it still needs further technical-operational policies as a supplement, and there are still discrepancies compared to the guidelines. We suggest that the by-laws of RSKO Jakarta are amended to adhere to the governmental guidelines and to establish supplementing technical-operational policies.
\end{abstract}

Keywords: hospital bylaws, adverse events, legal protection, health workers.

\begin{abstract}
Abstrak. Salah satu dari fungsi hospital bylaws adalah sebagai sarana perlindungan hukum bagi semua pihak yang berkaitan dengan rumah sakit. Perlindungan hukum sangat diperlukan saat tenaga kesehatan mendapatkan tuntutan. Salah satu hal yang dapat menimbulkan tuntutan adalah timbulnya Kejadian Tidak Diharapkan (adverse events). Tujuan penelitian ini adalah untuk mengetahui secara mendalam tentang bagaimana isi kebijakan hospital bylaws dalam upaya perlindungan tenaga kesehatan terhadap tuntutan adverse events dan kesesuaian isi kebijakan dengan pedoman yang ada. Desain penelitian dengan metode kualitatif. Hasil penelitian adalah kebijakan hospital bylaws RSKO Jakarta sudah memuat tentang upaya perlindungan hukum bagi tenaga kesehatan namun masih harus dilengkapi dengan pembuatan kebijakan teknis operasional lain dan masih ada ketidaksesuaian isi kebijakan Hospital Bylaws dengan pedoman. Saran yaitu agar dapat dilakukan perbaikan isi kebijakan hospital bylaws RSKO Jakarta, sesuai dengan pedoman pemerintah.
\end{abstract}

Kata kunci: hospital bylaws, kejadian tidak diharapkan, perlindungan hukum, tenaga kesehatan

\section{INTRODUCTION}

Hospitals are health facilities that provide in-patient, out-patient, and emergency care with all its supporting facilities. To be able to perform their activities, each hospital must establish rules that regulates how healthcare is provided, this is regulated into the hospital by-laws. Hospital bylaws is set by the owner of the hospital or his representative and acts as a guideline that regulates the procedures at the hospital.

The policies for hospitals bylaws are regulated by a Decree from the Ministry of Health of republic of Indonesia no. 772/Menkes/SK/VI/2002 on Guidelines for the Internal Regulations of a Hospital (Hospital Bylaws). The guideline stated that hospital bylaws consists of corporate bylaws and medical staff bylaws.

The rise in the education levels, general social economic conditions, and increasing awareness to gain justice from the public was accompanied with a recent boom in medical malpractice or negligence indictments. One of the reasons for an indictment is the occurrence of an adverse event, where a patient that is being treated in a hospital suffers an event that has negative consequences. In 2000, the American Institutes of Medicine presented a research on hospitals in Utah and Colorado, where the incidents of adverse events reached $2.9 \%$, in which the mortality rate was $6.6 \%$.

In New York, the incidence of adverse events was $3.7 \%$, with a mortality rate of $13.6 \%$. While the total mortality rate caused by adverse events for inpatient care patients in America was 33.6 million/year or 44,000-98,000/year. According to the World Health Organization (WHO) in 2004, the incidence of adverse events in America, the United Kingdom, Denmark, and Australia was $3.2-16.6 \%$.

Data from the Australian Patient Safety indicated that at least one out of every 10 hospitalized patients experienced an adverse event. In Indonesia, data on adverse events are hard to obtain. The following is the 2007 patient safety incidence report of each province. 


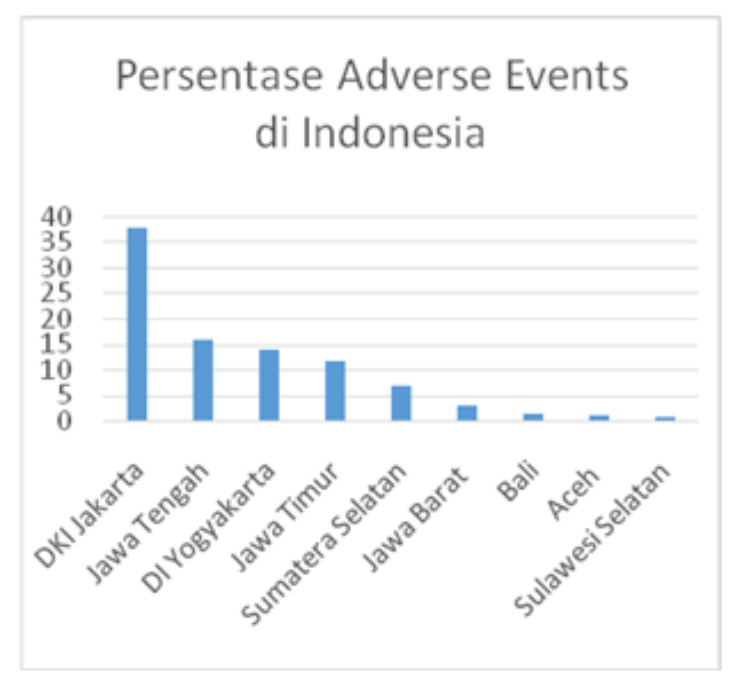

Picture 1. Patient safety incidence report in 2007 based on province. Source: the Ministry of Health, 2008

According to Van derSchaff (1992), there are several factors that causes adverse events to occur, they are 1) Technical factors, the hardware and software, 2) Organizational factors, the policies and protocols, and 3) Human factor, this is the human errors or transgressions. Some adverse events was caused by errors in the provision of care that can be prevented with a comprehensive care plan that considers the patient's rights. This is encompassed in a program that aims to improve the quality of care and reduce the occurrence of adverse events, the patient safety program.

RSKO Jakarta is a hospital directly under the Ministry of Health that is focused in the treatment for the abuse of drugs, alcohol, psychotropical drugs, and addictive substances (NAPZA). In 2010, RSKO Jakarta has established their corporate bylaws that contains the various regulations that guides the operational activities of the hospital. However, whether the bylaws have regulated the legal protection of the medical staff against indictments caused by adverse events and the supporting technical operational policies is still unclear. Tailored hospital bylaws should also conform to the guidelines set by the government.

\section{METHOD}

The research design used was the qualitative method. Studies was done by obtaining in-depth information on the healthcare, health staff, adverse events, patient safety activities, indictments and legal protection, and the contents of the hospital bylaws. The data was primary data from interviews with informants and secondary data from documents related to the research. The information was obtained from the health staff and members of the board and the related committees. The research instrument used is based on the in-depth interview guidelines. Data was collected by the researcher personally through in-depth interviews using the snowball method. During each in-depth interview, the research instrument used was an in-depth interview guideline, tape recorders to record the interview, and writing tools. The information gathered was the type of healthcare, number of health staff, types of adverse events, patient safety activities, types of indictments and the legal protection acts, and the contents of the hospital bylaws used at the RSKO Jakarta (corporate bylaws). The method, data source, and theories on the data was triangulated.

\section{RESULTS}

The healthcare provided at RSKO Jakarta consisted of out-patient and in-patient care, and its supporting services. This hospital was also one of the Institusi Penerima Wajib Lapor (IPWL) or one of the Institutions that must report to the government, and the type of patients that must be reported are drug addicts. The reporting is done by all the doctors, nurses, laboratory analysts, and psychologists. Not all the informants are able to describe the types of healthcare services provided.

The health staff accessible at the RSKO Jakarta are doctors (general practitioners dentists, and specialists), nurses, pharmacists (apothecaries and assistant apothecaries), public health staff (sanitarians and public health educators), nutrition staff (nutritionists), physical therapy staff (physiotherapists), and medical technicians (radiographers, laboratory analysts, and medical record experts). Members of the workforce are identified by grouping their educational backgrounds, job type, and functional positions.

\begin{tabular}{lccc}
\multicolumn{4}{c}{ Table 1. Total Health Staff. } \\
\hline Type of Staff & $\begin{array}{l}\text { Educational } \\
\text { Background }\end{array}$ & Job type & Functional Position \\
\hline Medical & 35 & 35 & 29 \\
\hline Nursing & 81 & 79 & 77 \\
\hline Pharmacy & 9 & 9 & 7 \\
\hline Public Health & 15 & 11 & 1 \\
\hline Nutrition & 7 & 9 & 7 \\
\hline Physical Therapy & 2 & 2 & 1 \\
\hline Medical Technician & 27 & 27 & 15 \\
\hline
\end{tabular}

Based on that grouping, there were several discrepancies, because some held jobs or positions that differ from their educational backgrounds, for instance staff with no health/medical background holding positions in the medical/health field. Therefore, some do not have registration papers (Surat Tanda Registrasi or STR).

Adverse events still occur at RSKO Jakarta. In 2011 there were 3 incidents (suicide, escapee, falls), in 2012 it was 5 incidences (delay in providing therapeutic instructions, falls, delay in providing therapy, delay in triage, and a mistake in providing anti-HIV testing), in 2013 there were 2 incidences (suicide and falls). 


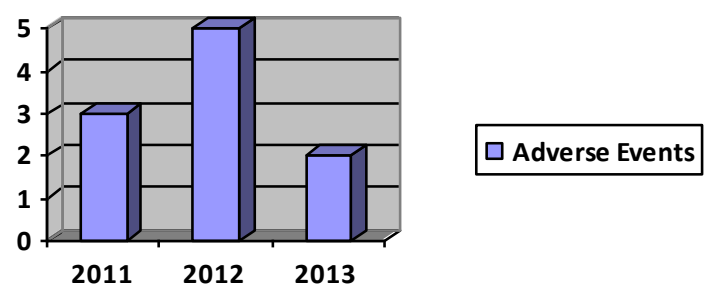

Picture 2. Adverse events incidence at RSKO Jakarta. Source: TKPRS Incidence Report.

The causal factors of an adverse event are the lack of supporting equipment and tools (bed securing devices and bathroom bars), mistakes and negligence (ineligible writing or incomplete writing of prescriptions, staff were unaware that an adverse event was occurring), lack of procedural policies and implements (no policies on waiting numbers at the pharmacy, no safety and fixation procedures for unconscious patients, incomplete names for drugs on the prescriptions, no patient handover and procedures at the radiology department, and no procedures for inpatient caretakers), and medical risks (medications that upsets the balance of the patient's system). During an adverse event, the management is based on the hospital's standard operating procedures (SOP), which is then followed with crisis management and intervention, establishing the event chronology, handling any injuries caused by falls by suturing wounds for instance, and follow-up-ing any mistakes such as giving the wrong medication by exchanging the medication. From the documentary studies of the Nursing SOP of the RSKO Jakarta in 2011, we discovered that several SOP has been modified to comply with the safety requirements, among them is the SOP for falls prevention in the wards, SOP for suicidal or self-injuring patients, and restraining patients.

The hospital already has Hospital Patient Safety Team (TKPRS) for patient safety activities that visits the patients and perform a patient safety greeting, but since their activities are heavily dependent on the directors, it is not at optimal performance. Each ward has its own patient safety champion and its own recording and reporting system. However, not all the medical staff have received education on patient safety.

So far, the claims caused by adverse events issued to RSKO Jakarta is still informal claims or complaints.

There are still members of the medical staff that are not aware that they have the right for legal protection, and the contract for non-civil servant medical staff do not mention legal protection. The types of legal protection that is available are facilitation, mediation, assistance, and defense.

Not all medical staff are aware of what is in the hospital bylaws, particularly the corporate bylaws. The hospital bylaws of RSKO Jakarta did not discuss the healthcare provided at the hospital in detail. It only stated that medical care and nursing care is a part of the duties of the Medical and Nursing Director. The hospital bylaws did discuss the medical staff multiple times, but its definition and job descriptions are not mentioned, and apparently the term 'medical staff' and 'health staff' is used interchangeably. It also did not mention anything about adverse events, patient safety, and the TKPRS. Details on legal claims are also not mentioned, it only stated 'legal issues'. Amongst the activities included in legal protection efforts that are discussed in job description and functions of the Ethical and Legal Committee are gathering, compiling, analyzing, and creating reports, evaluate the reports, provide legal counseling, facilitate multidisciplinary meetings, and analyzing and monitoring any legal problems.

The current supporting technical operational policies on legal protection for the medical staff includes:

1. Healthcare: The Chief Executive Officer Ordinance (CEO Ordinance) on staff placement, standard medical care procedures and clinical pathways, standard nursing procedures, standard operational procedures (SOP) on supporting services such as laboratory services, radiologic services, pharmaceutical services, nutritionists, etc.

2. Adverse events and patient safety: CEO Ordinance on the TKPRS, on the Hospital Healthcare Quality Committee, on the Hospital Accreditation Preparation Team, standard medical care and the clinical pathways, patient safety standards in the SOP for nursing care, SOP for supporting services such as laboratory services, radiological services, pharmaceutical services, nutrition, etc.

3. Medical Staff: CEO Ordinance on staff placement, human resources SOP on receiving new staff.

4. Legal protection and claims: CEO Ordinance on the Ethical and Legal Committee, the absence of SOPs for handling legal problems/claims, absence of medicolegal and ethicolegal experts that handles legal problems/claims.

In general, the corporate bylaws of RSKO Jakarta has complied with RI Health Minister's Decree No. 772/Menkes/SK/VI/2002 on the Guidelines for Hospital Bylaws, however some improvements on the benefits and functions of the bylaws are still necessary.

\section{DISCUSSION}

RSKO Jakarta provides in-patient care, out-patient care, and emergency care, as stated by Law No. 44/2009 on Hospitals Chapter I, article 1: "A hospital is a healthcare institution that provide comprehensive personal healthcare, which includes in-patient care, outpatient care, and emergency care". RSKO Jakarta also provides compulsory reporting for the health 
assessments of narcotic addicts. It is one of the compulsory reporting institutions (IPWL). The legal basis for the activities are Government Regulation No. $25 / 2011$ on the Implementation of Compulsory Reporting of Narcotic Addicts.

However, the existence of staff without the appropriate educational background and registration certificate for their profession is not in accordance of Law No. $36 / 2009$ on Health, where it is stated that health staff are persons that are dedicated in the health field and have the knowledge and/or skills obtained through education that, for certain types of professions, might require competence in order to provide healthcare. What is meant by competence is authorization provided through education after being registered and obtaining certification from the government according to the laws and regulations. Health staff registration is regulated in Health Minister Regulation No. 46/2013 on Health Staff article 1. According to Fitri (2013), based on the data obtained at the Bengkulu Provincial Health Services, there are will healthcare facilities and healthcare staff that did not have any registration, accreditation, and certification. Santoso (2005) also stated that there were problems in the certification of health staff of the Semarang City Health Service, many medical staff has not renewed their certifications as according to the new regulations, many medical staff still provide services or practices at more locations than what is legal, many nurses also do not have a license nor are they registered.

Various causal factors of adverse events are interrelated. Technical failures caused by the lack of equipment such as bed fasteners, interacts with human operator failure such as lack of patient control and organizational failure such as failure to implement the appropriate safety and securing procedures and policies. In addition, medical risks such as the side effects of medication that might disrupt the patient's balance system could also cause adverse events. The staff also plays a significant role in all four factors that cause the adverse events. The causal factors are identified by the 7 steps to patient safety at the hospital that is accomplished by integrating the risk management activities, studying and sharing the experiences on patient safety. The patient safety visits and greetings has complied with the patient safety activity guidelines, the 7 steps to patient safety at the hospital by performing leadership roles in improving patient safety. The reporting activities also follows those 7 steps.

The TKPRS was established in 2010. In 2013 it became a subcommittee of the Healthcare Quality Committee. The committee directly reports to the CEO. It is responsible executing for patient safety programs, from providing training, appointing and establishing the executors at each installation, recording and reporting each incident. The legal basis for the patient safety committee/team establishment is based on the Regulation of the Minister of Health of the Republic of Indonesia No. 1691/MENKES/PER/VIII/2011 on Hospital Patient Safety.

At RSKO Jakarta the adverse events claims are still in the form of complaints. According to Law No. 36/2009 on Health article 58, any health staff that performed any mistakes or is negligent in performing their duties are susceptible to persecution. It may take the form of monetary settlements for the victims or their families or criminal allegations. According to Turingsih (2012), the patient, as the plaintiff, may demand accountability for an act that breaches the law. It is possible for them to pursue civil and criminal allegations. The most common law used is article 359 and 360 of the Criminal Law (KUHP). According to Priharto (2010), article 359 of the KUHP is applicable for deaths caused by any mistakes of the doctor during practice.

According to Law No. 36/2009 on Health, the health staff has the right to obtain legal protection in performing their duties. According to Wahyudi (2011), the hospital is responsible for all the damages that occur as a part of the hospital's health staff's negligence, as stated in Law No. 46/2009. This law is the legal basis for demanding accountability from the hospital when one of their staff cause any injury. Njoto (2011) stated that civil sanctions to a business, including hospitals, that commits a breach of the Health Law is regulated by Article 201 of Law No. $36 / 2009$ on Health, which states "in addition to criminal incarceration and fines on the executives, corporations are also susceptible to criminal fines in amounts up to 3 (three) times of personal criminal fines". In addition to criminal fines, a corporation, including hospitals, may be further sanctioned with a revocation of the license to practice and/or a revocation of their legal body status (Article 201 section 2). The absence of the right to legal protection in the non-civil servant work contract is regulated in the Regulation of the Minister of Health of Republic of Indonesia No. 1199/MENKES/PER/X/2004 on Guidelines for Procuring Healthcare Staff by the means of a Work Contract at Government-Owned Healthcare Facilities.

The definition of healthcare services and health staff is not mentioned in the general clauses of the hospital bylaws of RSKO Jakarta. According to Law No. $12 / 2011$ on Establishing Legal Laws, the general clauses must contain the definition of the terms that is often mentioned in the regulation/law. The definition is expected to provide parameters in explaining the meaning of each article made and maintain the consistency of the terms used.

Failure to mention adverse events, patient safety, and TKPRS in the hospital bylaws suggests that patient safety is not a priority nor is it emphasized when performing hospital activities. Although in actuality it 
is extremely important and protects the patient as the recipient and healthcare staff as the provider. Patient safety also ensures the safety of patient care.

The term 'allegations' is not used in the hospital bylaws, the term used is 'legal issues/problems'. Legal problems are considered sufficient as a representation, because it covers both the criminal and civil laws, for demands for compensation from the staff or the hospital.

Legal protection is included in the hospital bylaws, it is part of the job description and duties of the Ethical and Legal Committee. The legal basis for this committee is the Regulation of the Minister of Health of Republic of Indonesia No. 1045/MENKES/PER/XI/2006 on the Guidelines for Hospital Organization within the Health Ministry that stated a hospital must have at least two committees, the Medical Committeee and the Ethical and Legal Committee. This is based on the Minister of Health Decree No. 772/MENKES/SK/VI/2002 that states that one of the functions of hospital bylaws is to provide legal protection for all parties related to the hospital. According to Soetoprawiro (2002), legal protection is essentially an effort from the authorities to provide assurance and facilitate each citizen in fulfilling their rights and duties optimally peacefully.

Various technical operational policies in the form of an Ordinance from the CEO and SOPs has been established to provide legal protection for the healthcare staff when an adverse event happens, but the details, such as its mechanism, the actors, and specific SOPs for the mechanism has not been established. According to Badahura (2013), hospital bylaws are written basic laws that can be used as a guideline for the staff and employees to perform their duties professionally and it also provides clear legal basis. However, technical operational policies that supports the bylaws are still necessary in the actually application.

The hospital bylaws of RSKO Jakarta has less benefits than what is mentioned in the Minister of Health Decree No. 772/MENKES/SK/VI/2002. The bylaws also do not mention its own functions. The benefits are relatively similar to its functions, which is perhaps caused by the lack of accuracy in its creation. The bylaws has not been revised since it was first established in 2011. There were only 4 (four) types of committees included in the Minister of Health Decree No. 772/MENKES/SK/VI/2002, the Ethical and Legal Committee and the TKPRS was not included. The four committees suggested are:

1. Patient care review committee.

2. Finance and budgeting monitoring committee.

3. Houseworks monitoring committee.

4. Medical appointment advisory committee.

This does not provide adequate support for improving the quality of healthcare at the hospital. In addition, patient safety is one of the important components of hospital accreditation, and therefore must be regulated by one of the hospital committees.

\section{SUMMARY}

Hospital bylaws should be a way to provide legal protection for the healthcare staff by including the mechanisms for legal protection. In summary, the hospital bylaws policies, particularly the corporate bylaws have included legal protection efforts against allegations caused by adverse events, however it still requires improvements and must be accompanied by creating its supporting technical operational policies. In general, the hospital bylaws have satisfied the current guidelines.

Since patient safety and legal protection for the staff is impotant in the provision of healthcare at the hospital, the hospital bylaws guidelines must be revised to establish a Patient Safety Team/Committee and a Ethics and Legal Committee.

\section{REFERENCES}

Badahura, Ilham. (2013). Penyalahgunaan kewenangan Pihak rumah Sakit terhadap Pasien Ditinjau dari Sudut Hukum Kesehatan. Lex et Societalis Vol. 1 No 4 (2013). http://ejournal.unsrat.ac.id/index.php/lexetsocietatis/article/view /2780 diunduh pada 28 Mei 2014 jam 14.07 WIB

Fitri, Adlin. (2013). Evaluasi fungsi regulasi Dinas Kesehatan Provinsi pada Sektor Kesehatan di Provinsi Bengkulu. http://etd.ugm.ac.id/index.php?mod=penelitian_detail\&sub=Pen elitianDetail\&act $=$ view\&typ $=$ html\&buku_id $=64022 \&$ is_local $=1$ diunduh pada 27 Mei 2014 jam 08.17 WIB.

Kementrian Kesehatan Republik Indonesia. (2002). Keputusan Menteri Kesehatan Nomor 772 Tahun 2002 Tentang Pedoman peraturan Internal Rumah Sakit.

Kementrian Kesehatan Republik Indonesia. (2011). Peraturan Menteri Kesehatan republik Indonesia No. 1691/MENKES/PER/VIII/2011 tentang Keselamatan Pasien Rumah Sakit.

Kementrian Kesehatan Republik Indonesia. (2013). Peraturan Menteri Kesehatan Nomor 46 Tahun 2013 Tentang Registrasi Tenaga Kesehatan.

Njoto, Haryanto. (2011). Pertanggungjawaban Dokter dan Rumah Sakit Akibat Tindakan Medis Yang Merugikan dalam Perspektif UU No 44 Tahun 2009 tentang Rumah Sakit. http://jurnal.untagsby.ac.id/index.php/dih/article/view/263 diunduh pada $24 \mathrm{Mei}$ 2014 jam 10.15 WIB.

Republik Indonesia. (2011). Peraturan Pemerintah Nomor 25 Tahun 2011 Tentang Pelaksanaan Wajib Lapor Pecandu Narkotika.

Republik Indonesia. (2011). Undang-Undang Nomor 22 Tahun 2011 Tentang Pembentukan Peraturan Perundang-Undangan.. Lembaran Negara Republik Indonesia Tahun 2009 Nomor 82, Tambahan Lembaran Negara Republik Indonesia Nomor 5234. Jakarta: Sekretariat Negara.

Santoso, Bowo. (2005). Pengembangan Sistem Informasi Perijinan Tenaga Kesehatan Mendukung Pemantauan Program Perijinan Tenaga Kesehatan Kota Semarang. http://eprints.undip.ac.id/4389/ diunduh pada 27 Mei 2014 Jam 08.19 .

Soetoprawiro, Koerniatmanto.(2002). Pengaturan Perlindungan Hakhak Perempuan dan Anak-anak dalam Hukum Kewarganegaraan Indonesia dalam Jurnal Hukum Pro Justitia Tahun XX Nomor 3 Juli 2002. Bandung: FH UNPAR.

Supriadi,Willa Chandrawila.(2001). Hukum Kedokteran. Bandung: Penerbit Mandar Maju.

Taylor, Robert J. (1994). The AUPHA Manual of Health Services Management. Maryland: Aspen Publisher. 
Trijono, Rachmat. (2013). Dasar-dasar Ilmu Pengetahuan PerundangUndangan. Jakarta: Papas Sinar Sinanti.

Turingsih, RA Antari Inaka. (2012). Tanggung Jawab Keperdataan Bidan dalam Pelayanan Kesehatan. Jurnal Mimbar Hukum Vol 24, No 2 (2012).

http://mimbar.hukum.ugm.ac.id/index.php/jmh/article/view/390/ 239 diunduh pada 10 Juni 2014 jam 06.05 WIB.

University of Tennessee Health Science Center. (2003). Legal Issues in Healthcare; Consent. A Guide for Health Care Providers in Tennessee.

Usman, Mohammad Uzer. (2006). Menjadi Guru Profesional. Bandung: Remaja.

Wahyudi, Setya. (2011). Tanggung Jawab Rumah Sakit terhadap Kerugian Akibat kelalaian Tenaga Kesehatan dan Implikasinya. Jurnal Dinamika Hukum Menuju Hukum yang Humanis. Vol 11, N0 3 (2011). http://dinamikahukum.fh.unsoed.ac.id/index.php/JDH/article/vie w/178 diunduh pada 24 Mei 2014 jam 09.15 WIB

Wibowo, Adik. (2014). Metodologi Penelitian Praktis Bidang kesehatan. Jakarta: RajaGrafindo Persada. 